\title{
Managing Online Presence in the E-Learning Environment: Technological Support for Academic Staff
}

\author{
Nurul Islam ${ }^{1}$, Martin Beer ${ }^{1}$, Frances Slack ${ }^{1}$ \\ ${ }^{1}$ Sheffield Hallam University, C3RI, Cantor Building, 153 Arundel Street, City Campus, Sheffield, S1 1WB, UK \\ Correspondence: Nurul Islam, Sheffield Hallam University, C3RI, Cantor Building, 153 Arundel Street, City Campus, \\ Sheffield, S1 1WB, UK
}

Received: December 8, 2014

Accepted: December 23, 2014 Online Published: March26, 2015

doi:10.11114/jets.v3i3.744

URL: http://dx.doi.org/10.11114/jets.v3i3.744

\begin{abstract}
Over the last two decades the use of E-learning technology increased to such an extent that the role of the traditional academic has been forced to change. Focusing on academics' views, this study examines their interactions in the E-learning environment and whether online learning applications have increased academic workload (Eynon, 2005; Olaniran, 2006). This study also identifies how their role has changed and the underlying factors which may cause negativity in their working environment.

Based on a literature review and twelve interviews with academics the work suggests that online learning applications have increased workload. For some academics the use of E-learning technology in UK higher education can be a full time occupation. It is evident from the data that the drawbacks to current E-learning technology outweigh the number of benefits. A key concern is the high number of working hours spent on E-learning systems by academics. This research states unequivocally that the level of complexity for some academics is daunting as well as frustrating. A key finding from this research is a wish list made by academics that can help in their role as teachers in utilising E-learning technology. Managing expectations of academics is vital to the success of E-learning technology in higher education institutions.
\end{abstract}

Keywords: E-learning, VLE, higher education, effects on academics, permanent online presence

\section{Introduction}

During the last twenty years computer based learning has emerged as the innovative delivery method for education (Moos \& Azevedo, 2009). In some instances internet based education has taken the place of traditional classroom learning (Zhang et al., 2004; Huddlestone \& Pike, 2008).

The need for higher education institutions to support their academics in a time of change is enormous. Often academics are left to cope with the changes by way of minimal guidance and support. Because of these enormous changes the support required for academics has never been more important.

The student's perspective has been covered by various researchers (Wang \& Wang, 2009; Hardaker \& Singh, 2011; Macharia \& Pelser, 2012). However, very little research has been undertaken on the perspective of the academic staff. This is at a time when administrators and academic managers are increasingly putting pressure on academics to incorporate technology in their teaching (Eynon, 2005; Olaniran 2006). This study focuses on academics needs, the problems they are facing, the perception they have and the ways technology can be adjusted to suit their needs

'E-Learning' refers to all forms of electronic supported learning. In this paper it refers to electronic technology, networked or stand alone, whether the hardware is hand held such as in mobiles, desk bound such as the personal computers (PC's) or laptops.

\section{Literature Review}

To summarise, the reason for its success is that use of E-learning systems would result in a higher level of student involvement (Hardaker \& Singh, 2011; Macharia \& Pelser, 2012). E-learning can be superior to face-to-face learning in terms of quality interaction and timely feedback with good course design which untangles the geographical limitations to education (Chen \& Yang, 2006). The financial benefits as a result of enrolling large quantity of students made E-learning systems irresistible to institutions. 


\subsection{Underlining Factor to Growth}

The rise of E-learning technology used by higher education institution can be attributed to globalisation. This is referring to a political and economical phenomenon, a worldwide integration of views, culture and products (Hall, 1996; Clegg et al, 2003; Sidhu, 2005; Spring, 2008; Raghuram, 2013). The previous Labour Government in 1997 used the globalisation argument to justify and encourage UK higher education institutions to adopt E-learning technology. Since then Government agenda remains the same to push forward with technology to enhance learning (Brown, 1999; Mee, 2012; Jackson \& Fearon, 2013).

\subsection{The Six Challenges}

The challenges faced by academics are many where further research is required. The following is a list of six challenges identified from research literature:

\subsubsection{Learning Style and Cultural Challenges}

Everyone has their own learning style along with their cultural influences; the students who are taught using their own learning style taking into consideration cultural aspects of individuals will perform better academically (Sywelem et al, 2012). Phipps \& Merisotis (1999: p.3) recommend that "there needs to be more emphasis on individual differences such as gender, age, educational experience, motivation and learning style" implying that current research on E-learning does not identify individual needs. Another issue is that instructors fail to take into consideration student cultural differences, pedagogy and technology when designing course materials.

\subsubsection{Pedagogical E-learning Challenges}

Online development and delivery requires new pedagogical approaches, challenging previous practices with regards to assessment, group interaction and student/teacher dialogue. Leask (2004: p.347) points out that E-learning technology was used in ways that do not enhance teaching and learning, for example "dumping large amounts of text onto a website". For academics to successfully make the transition to become online teachers or learning facilitators, they need to do more than just develop new technical skills, it should be pedagogy based (Morley, 2010). Having a well designed course that is pedagogically focused, and academics understanding the different strategies of online learning with the understating of diversity and context, group dynamics require institution management support to market the pedagogical benefits of online learning with practice examples that academics can relate to so they are encouraged to use the E-learning technology (Jackson \& Fearon, 2013).

\subsubsection{Technological Challenges}

There are more than 35 E-learning technology vendors in the market (Edu tools, 2009). E-learning technology at its current level does not have a facility to establish the teacher's presence or influence, as the student has the same capacity as the teacher. An institution's technological support appears to be inadequate to support online learning in the modern educational environment where cultures and languages are diverse (Farmer, 2004).

There is a complex process of managing multiple technologies where old systems meet new applications. This is a challenging process affecting academics (Nielsen et al. 2011). There has been much research as how better to use online technology but little research has been conducted on the online interaction and participation between academics and students. The quality of interaction and its effectiveness, the interaction that uses online asynchronous communication design has yet to be adequately investigated (Blignaut \& Trollip, 2003; Nandi et.al 2012).

\subsubsection{Technical Training Challenges}

Academics complained that training was not as they expected. It was mostly an overview session without emphasis on practice. It did not give them enough confidence. It was not inspiring enough for them to carry on learning. The training session was badly planned with errors, rushed and not fully functional (Salmon, 2000; Gerrard, 2002; Jackson \& Fearon, 2013).

\subsubsection{Time Management Challenges}

According to Reeder et al. (2004) some of the "cyberculture values" are characterized by speed, reach and quick response. A few researchers stated that academics should always maintain a vigorous presence on online discussion boards so they control discussion, provide answers and feedback so students do not disengage from the course (Nandi et al., 2012).

A case study conducted by Mihhailova (2006) found time management is complicated as answering queries or preparing lecture notes takes longer than expected, and there is "no compensation system or clarity in pay for the lecturers" (p.275). The ramification of these challenges is how to balance the workload.

Academics in the UK are finding it difficult to keep pace with postings in the discussion boards and forums. "The 
volume of traffic on the forum affected the time needed to keep up to date" (Cornelius \& Macdonald 2008, p.52), causing academics sometimes to skim over posted messages. Other academics, who are persistent about checking every posting, become selective when traffic increases.

Conrad (2004) states that E-learning becomes 30\% more time consuming for academics than traditional classroom teaching, and E-learning increases academics efforts by $14 \%$ to teach effectively (Tomei, 2006).

\subsubsection{Health Challenges}

One major factor why the industry was keen on E-learning was its availability 24 hours a day and their workforce preferred convenience and flexibility. For the reason of convenience and 24 hours availability institutions must heed the warning: "The social dynamics of education changes once participants choose online education" (Smith et al., 2003, p.101).

Research conducted by Allan \& Lawless (2004) explains that as online learning and collaboration increases it is believed this can itself cause stress. If an educational establishment does not create the correct nurturing then no doubt it will affect cooperation and communication, which will eventually lead to reduced job satisfaction and stress (Zeffane \& McLoughlin, 2006; Jackson \& Fearon, 2013).

\subsection{Recent Trends in E-learning}

Recent trends in E-learning technology, as Ge et al. (2010) state for institutions and learning providers' ubiquitous services, are overwhelming and are the future. Shu (2010) encourages and argues that the implementation of new evaluation methods such as 'learning portfolio, work display and work group discussion' (p.408) are the 'new ways of thinking' (p.409). Xin (2010) discusses the second and third generation of E-learning tools where learning is moved from teacher oriented learning to 'student-centred learning' (p.496).

Current uses of E-learning technology include podcasts where academics record their lecture or instructions; students are then able to download the podcast into an iPad. Students are able to communicate between themselves and with academics using mobile texting services and phoning the academics with their mobile during a student group session or working individually to clarify any issues. They also have the option of going to blogs and forums relating to their subject to get instruction, ask questions to clarify issues where an academic will often check and answer any relevant queries (Evans, 2008; Copley, 2007).

\section{Method}

This research was an inductive process and thematic analysis was utilised to structure the raw data collected from twelve interviews.

The research interviews were semi-structured and consisted of six main questions on the experiences of academics in the use of E-learning technology including the challenges they faced. The criteria for choosing interviewees were set to: academic staff can be of any gender, be of any age, be from any geographical locations within UK and must hold part-time or full-time post as an academic in any of the UK's recognised higher education institutions.

All interviews were tape recorded and then transcribed for analysis; pseudonyms are used for interviewed participants. All data collected went through an inductive qualitative process which involved reading the data, categorising, and data reduction by constantly comparing data, followed by continued revision and refinement of codes in order to draw conclusions. The iterative analysis continued until it was not possible to find new categories or relationships that would add value to the research findings.

\section{Findings}

\subsection{Interviewee's Technologies}

The academics had no particular preference to any specific E-learning platforms. They reported that the E-learning platform is a tool to do a job well. Lecturers did not distinguish the different components that are put together to make up the E-learning system. They saw the Blackboard system, email, internet web pages, the multimedia tools that are used to record images and videos, and even Microsoft Office, power point and other applications used for teaching, as the same entity, i.e. for them all these entities make up the E-Learning system.

The most popular E-learning system in UK institutions, both according to the literature review and to the lecturers interviewed for this study is Blackboard.

\subsection{E-learning Technology Changing Academics Role}

All lecturers agreed that the role of a teacher has not changed fundamentally, but E-Learning technology has affected it and changed it in minor ways and it will continue changing depending on the speed of innovations. All lecturers reported that these changes are related to increased hours of online activity, communication/interaction between 
lecturers and their students, flexibility, and an increase in distance learning students.

"I think that we are made to do more for ourselves now" Dr J Interview

"No, not really because the traditional delivery of lecture is there" Dr A Interview

Lecturers are concerned that institutions are rushing ahead and moving too fast. Institutions are spending huge amounts of money procuring new hardware and software so academics can use technology. Sometimes these decisions of huge costs are done in haste without bringing about the benefit they hoped for. The institution should hold on, assess and evaluate the situation before moving any further.

\subsection{Uniformity}

Several of the lecturers pointed out the uniformity issues with Blackboard system. They described that every teacher has his/her own way of doing things and everyone organises materials and content differently. This causes problems with students and staff as they are not familiar with the layout, especially if their technical competency is basic or the technology is too complex.

\subsection{Disadvantages of E-learning Technology}

Twelve advantages and 30 disadvantages of using the E-learning technology were stated by academics in the interviews (see table 1). They are listed in order of frequency, where the first five listed advantages and disadvantages have been mentioned three or more times by different academics and all the rest have been mentioned at least once.

Table 1. Advantages and disadvantages of E-learning technology in higher education institutions

\begin{tabular}{|c|c|}
\hline Advantage & Disadvantage \\
\hline 1. Flexibility for academics & 1. Time spent learning the E-learning system \\
\hline 2. Ease of uploading/downloading materials & 2. Loss of face to face contacts with students \\
\hline $\begin{array}{l}\text { 3. Technology helps and enables them to reach } \\
\text { people/students all over the world }\end{array}$ & 3. Copying and memorising materials by students \\
\hline 4. Easier to search for information & 4. The downtime technical problems in IT/network \\
\hline 5. Email communication & $\begin{array}{l}\text { 5. Increased work hours. For example the materials have to be crystal clear, and } \\
\text { even a single line takes time and thought to write upload and communicate. }\end{array}$ \\
\hline 6. Easy to prepare notes & 6. Increased work hours due to online assessment \\
\hline 7. It serves as storage space & $\begin{array}{l}\text { 7. Lot of red tape, i.e., every text that is uploaded has to be verified and checked } \\
\text { by senior management }\end{array}$ \\
\hline 8. Transmission of video tutorials & 8. Increase in copying and repetition of same materials and tasks every term \\
\hline $\begin{array}{l}\text { 9. Interesting materials can be passed around rapidly } \\
\text { and with ease. }\end{array}$ & 9. Copyright problems for published and unpublished work \\
\hline 10. Reduction of printing lecture notes & $\begin{array}{l}\text { 10. Some lecturers find use of E-learning system difficult and complex, } \\
\text { especially senior lecturers }\end{array}$ \\
\hline $\begin{array}{l}\text { 11. The notes can be left online for a long period of } \\
\text { time }\end{array}$ & 11. Institution treating lecturers as a commodity/product \\
\hline 12. Increase in student numbers & 12. It does not reduce repetition, i.e., you instruct the E-learning system then has \\
\hline \multirow[t]{19}{*}{ Especially in distance learning } & to be repeated/announced to students \\
\hline & 13. Compelling, pressurising and forcing teachers to use the system \\
\hline & 14. It's more suitable to Undergraduate teachers than for research supervisors \\
\hline & 15. Students and teachers become less creative \\
\hline & 16. Lecturers becoming facilitators rather than good teachers \\
\hline & 17. Stress and frustration of using and learning the technology \\
\hline & 18. Software crashes, freezing and slowing down \\
\hline & 19. Always software updates to add a new function or to fix bugs \\
\hline & 20. Difficult and complex to use \\
\hline & 21. Lack of uniformity \\
\hline & $\begin{array}{l}\text { 22. Psychologically limits the students academically that no further reading is } \\
\text { required, the notes provided are sufficient }\end{array}$ \\
\hline & $\begin{array}{l}\text { 23. The routine tasks the E-learning system is used for can be done by other } \\
\text { means such as creating lecturers own websites to upload / download information } \\
\text { and using alternative emails to communicate }\end{array}$ \\
\hline & 24. Some lecturers are 'technophobic' or against technology as a whole \\
\hline & $\begin{array}{l}\text { 25. Creates a digital divide between mature lecturers and younger technology } \\
\text { competent lecturers }\end{array}$ \\
\hline & 26. E-learning software does not identify the individual needs of the student \\
\hline & 27. Moral objection: E-learning System can be used to discriminate against poor \\
\hline & $\begin{array}{l}\text { students who are unable to pay their fees (students get locked out of the system } \\
\text { for non-payment of fees) }\end{array}$ \\
\hline & 28. Some functions require third party support which wastes time \\
\hline & 29. Some students do not use the system causing replications of tasks \\
\hline
\end{tabular}

This table shows the suggestions made by academics of the benefits and drawbacks of E-learning technology.

\subsection{Longer Working Hours}

Analysis of interview data shows that academics are spending an increased amount of time using the E-learning system. 
One academic's use of E-learning system is like a full time occupation on top of teaching, as he uses up to 40 hours a week. Five lecturers said they spend between 12- 20 hours a week and the other six lecturers use it between 2 and 10 hours a week. Four academics felt they spend too much time with E-learning technology.

"It's a full time job in addition to teaching", Dr A.

"It's about 50\%." [Of time spent with E-learning a week], Dr B.

"20 hours plus a week", Dr C.

"I would say about 12 or 13 hours per week preparation, and the presentation about 13 to 15 hours per week", Dr A.

Time was divided on E-learning platform such as Blackboard or Moodle, research, and preparing the materials for the E-learning platform.

"I would probably use the computer for maybe six of those eight hours in preparation and that would mean looking at old lessons and creating worksheets for the students on the computer" Dr D.

One lecturer estimated that in his institution $50 \%$ of students do not use the E-learning platform provided by the institution. As a result he spends time updating the E-learning platform at the same time making announcements, handing out materials and sometimes sending email to students' personal email accounts to make sure that students are engaged with the course content. Generally, he felt that students don't take proactive measures of preparation and learning. The majority of the time students turn up to class with a pen and paper expecting to be spoonfed. If all students were required to use the E-learning system then it would save lot of time and effort for lecturers.

"You are compelled to use the technology sometimes to send your stuff through online and most of the time students are waiting for you as well to use that software or that system to get access of what you have uploaded.

Even though if I can see them they would still ask me that have you done this have you done that and I would say that I would do this tomorrow or next time" Dr. D.

Another reason for the increase in online activity for lecturers is the need to make teaching materials easy to use and understand. Lecturers report that to write a single line can take lot of time and thought, particularly as writing must be error-free and free from confusion, misunderstanding and misrepresentation.

"When you are teaching in a trusted environment, you don't have to write every word down, you might talk around a subject it but in a virtual learning environment everything has to be crystal clear even the simple thing, even a simple online article, make sure that it's not misunderstood because in the classroom some people will say, can you explain that a bit more" Dr. I.

\subsection{Frustrated and Annoyed Academics}

Seven lecturers said using technology often caused them to become frustrated, while two lecturers said it caused them annoyance rather than frustration. Three lecturers said they support the use of E-learning technology because the more use the better it is.

There is no pattern in subjects, age, or experience between those lecturers who reported feeling frustrated with using technology and those who did not.

\subsection{Academics Wish List}

Academics suggested many ideas on how to improve the technology to support their roles as teachers/facilitators and to better manage the drawbacks in the current E-learning platforms. Table 2 lists the academic suggestions. 
Table 2. Academics' suggestions

\begin{tabular}{|c|c|}
\hline Suggestion number & Suggestion \\
\hline 1 & Making sure the right kind of support is available \\
\hline 2 & To manage expectations \\
\hline 3 & $\begin{array}{l}\text { Changes in administration, organisational changes affects } \\
\text { E-learning }\end{array}$ \\
\hline 4 & $\begin{array}{l}\text { Students should be informed of the support that is available } \\
\text { to them }\end{array}$ \\
\hline 5 & Organisation improvements are required \\
\hline 6 & Feedback should occur more promptly \\
\hline 7 & Academics should not update blackboard \\
\hline 8 & $\begin{array}{l}\text { Usage of other email applications create the extra hours of } \\
\text { work }\end{array}$ \\
\hline 9 & $\begin{array}{l}\text { Student monitoring system should be included in E-learning } \\
\text { environment. }\end{array}$ \\
\hline 110 & Assessment should be improved and included in E-learning. \\
\hline 11 & Always complement learning with video feed \\
\hline 12 & $\begin{array}{l}\text { The E-learning platform online help should be made easier } \\
\text { to understand }\end{array}$ \\
\hline 13 & The interface can be more intelligent \\
\hline 14 & $\begin{array}{l}\text { E-learning system should automatically create relevant } \\
\text { citation/links to articles and books }\end{array}$ \\
\hline 15 & To have a resilient network infrastructure \\
\hline 16 & Lecturers use SKYPE to communicate with colleagues \\
\hline 17 & $\begin{array}{l}\text { The training should be during working hours and during } \\
\text { term-times }\end{array}$ \\
\hline 18 & $\begin{array}{l}\text { Create general GUI standard and standardise the operational } \\
\text { functions. }\end{array}$ \\
\hline 19 & $\begin{array}{l}\text { The E-learning system does not cater for foreign student } \\
\text { needs. }\end{array}$ \\
\hline 20 & $\begin{array}{l}\text { As the roles are changing more could be done to notify } \\
\text { lecturers of health hazards. }\end{array}$ \\
\hline 21 & E-learning systems at present are not flexible. \\
\hline 22 & $\begin{array}{l}\text { Lecturers to increase motivation aspects in teaching in } \\
\text { E-learning environment. }\end{array}$ \\
\hline 23 & Social networking aspects should be included in E-learning. \\
\hline 24 & Interactive whiteboard to be used with Blackboard. \\
\hline 25 & $\begin{array}{l}\text { Blackboard does not have control, authority of lecturers in } \\
\text { the discussion rooms. }\end{array}$ \\
\hline 26 & $\begin{array}{l}\text { Removing the mouse and the keyboard which can save time } \\
\text { and operating effort. }\end{array}$ \\
\hline 27 & Institution to allows lecturers use open source software. \\
\hline 28 & Make Blackboard similar to BBC Learning. \\
\hline 29 & $\begin{array}{l}\text { The E-learning system is not required, traditional system is } \\
\text { sufficient. }\end{array}$ \\
\hline
\end{tabular}

This table lists the suggestions made by academics on how utilisation of E-learning technology can be improved to support their roles as teachers/facilitators and how better to manage the drawbacks in current E-learning platforms.

\subsection{Training Required for Academics}

"For someone who finds Word difficult, Blackboard can be intimidating" Dr. K.

Nearly all of the lecturers interviewed said they attended training when they joined their respective institution or when E-learning initially was installed.

However, some of the academics were dissatisfied, they stated the training was very theoretical and they did not get the chance to experiment or get sufficient hands-on training. They recommended the training needs to be completely changed. Rather than attending a theoretical lecture on how to use the technology, they would have preferred to have an instructor next to them while they were experimenting with the system so that they could be given guidance by them.

One lecturer did not attend any form of E-learning training although the institution invited him. He suggested several reasons why he did not attend. These included: he does not like technology it is too complex, he wants nothing to do with E-learning, it will not benefit him in any way, and it would be a waste of time. However he reported that he may be persuaded to attend in the future if the training was less technical, and was short and sharp to the point.

Those who reported that the training they received was inadequate tended to be senior lecturers, more experienced and specialised in non-technical subjects such as Business, Law, Languages and Health Sciences. Those who stated that 
training was adequate tended to be more junior staff and to come from Science, IT and Engineering subjects.

\section{Conclusion}

The majority of research in E-learning field is focused on the needs of the student and little research has been undertaken that discusses the view point of the academic staff. This paper contributes to the academic perspective.

\subsection{More Disadvantages Listed Than Advantages}

It is evident that the drawbacks to E-learning technology vastly outweighed the number of benefits, twelve advantages in contrast to thirty disadvantages (see Table 1) have been highlighted. It is apparent that the advantages are so beneficial that the implementation of E-learning technology is deemed worthwhile to the institutions, that they can bear the greater number of disadvantages. There has been much published literature that discusses issues with E-learning technology but none of the papers list thirty disadvantages. This suggests E-learning has changed academics' roles in a negative way.

\subsection{The E-learning Wish List}

Through the interviews academics suggested a wish list that would help them with E-learning technology. The wish list comprised thirty-one suggestions of how E-learning can be adjusted to help an academic in their role (see Table 2). A key contribution of this research is that majority of the suggestions were not technical ones, rather they were managerial issues, or identified the need for effective support and enhanced training.

The technical suggestions that academics mentioned are solutions already in existence in the market through various software vendors. It is possible that institutions have all the applications that academics want, however not all academics are aware of it. For example, visual video conferencing through SKYPE is available, and for uniformity there are configuration settings in Blackboard and Moodle to create a standard compatibility and integration. Even though Blackboard is limited to its corporate environment, however, applications such as Moodle are open source and can be incorporated and integrated with other systems.

\subsection{The Need for E-Learning Platforms}

Since so many negative points were raised by academics about E-learning, the fact that Blackboard is the main supplier to UK universities appears to reflect badly on Blackboard. It is interesting to note that none of the academics mentioned a single disadvantage of applications such as Microsoft Office Suite, the Internet, email, or conferencing tools such as SKYPE.

All academic staff interviewed pointed out benefits and drawbacks of the technology. Lecturers who do not use technology and those who are in opposition to the E-learning system suggested some benefits. This demonstrates two facts: firstly E-learning is here to stay for good and secondly the technology has serious challenges and expectations to meet as there were more negative than the positive points.

\subsection{Replace the Current Software Vendors.}

Is paying large sums of money to software vendors such as Blackboard worth the price, if the main reason for academic use is for a central repository, email and controlling access? Currently other free application exists to do all these functions without a fee. Why not use Facebook, Youtube, Skype and various Google applications as an E-learning platform for free?

\subsection{Academics Spend Too Much Time on E-learning}

The numbers of hours some academics spend on the E-learning system are high. In this study academics have stated they use the system like a full time occupation, i.e. up to 40 hours per week on top of their teaching. Other academics stated they use up to 20 hours a week on top of their teaching activities. It is hard to believe any organisation could have foreseen such a drastic effect on their staff or understood the ramification of such a tool. The existing literature does not highlight the increase in working hours to such an extent.

Some of the reasons stated by academics why so much time is taken: creating quality presentation, answering questions using emails, forums, chat, students expecting instant feedback, and interaction with other social media can easily add up hours without an individual noticing.

\subsection{Changes to Academic Roles}

All lecturers stated changes in their roles are related to increased hours of online activity. The effects of online learning are the increase in online activity, leading to longer working hours. Although the role as a teacher has not changed fundamentally, it has affected how learning is delivered and how it is communicated. It has affected academics' understanding of the learning style of their students, not able to see them and interact with them. Academics have mentioned they are being pressured to do more work. Although hard work would not be an issue for most academics, to 
do the work preparation as required can take more time than expected in an E-learning environment.

The training in technology, understanding individual learning styles, how they will be able to command the virtual environment, all these things add to working hours and add to the changes in way academics manage time and carry out their teaching activities.

The role for a traditional academic is known and established. The role for an academic who teaches only online courses is defined in their employment contract. The E-learning issue rose from academics who teach in a blending learning environment where traditional and online technologies are merged. The many disadvantages above listed are from the blended learning academics.

\subsection{Complexity is Underestimated}

An academic eloquently stated some academics find Microsoft Word difficult so E-learning is daunting for them. Although some literature has highlighted training requirements, this research states unequivocally that the level of complexity for some academics is daunting. Some academics do not use E-learning and are resistant to E-learning technology, and there is no doubt that this is a symptom of complexity of E-learning technology.

\subsection{Frustrated and Annoyed Academics}

This research reveals that academics often get frustrated with E-learning technology as a result of coping with multiple disadvantages. The solution to this problem is to reduce as many of the disadvantages as possible; in theory removing one disadvantage will remove a fraction of academics' annoyance and frustration. Other academics stated they were pressured into using the technology, and for these academics the usage of technology causes them frustration or annoyance. However they have stated they would have a go if they could be convinced or felt that technology could help them to facilitate learning. This indicates that institutions are not doing enough to reach out to these academics or are using an incorrect way of inviting academics to try out E-learning technology.

\section{Further Research}

It has been over a decade since E-learning was implemented across UK higher education institutions and yet it is not clear if this technology has been used effectively since it was deployed. The creation of a framework that has credibility amongst institutions is required to determine effectiveness of E-learning, and a further study of this type is needed.

It would be of interest to know to what extent software vendors' marketing statements and description of E-learning is shaping academics' expectations. This research revealed from statements by academics that what they initially thought of an E-learning system was to resolve all their problems, but this has fallen short.

Cheon et.al, (2012) wrote about a gap in the literature in factors affecting acceptance of mobile learning in Higher Education institutions. There is no doubt this also applies to academics, and factors affecting the acceptance of m-learning. What effects does m-learning have on academics? What are the technical and training requirements for academics in m-learning institutions?

The role change in academics is initiated by technology; further studies should investigate how management approaches should change according to academics' needs.

Research exploring how institutions plan to resolve or compensate academics working extra hours to fulfil their role would be of interest to academics. Those academics who spend long hours answering student emails, and doing research for presentations require compensation and recognition.

Academics have mentioned the effects of technology, and further research on how to manage expectations in an E-learning environment would be of interest.

\section{References}

Allan, J., \& Lawless, N. (2004). Understanding and reducing stress in collaborative e-Learning. Electronic Journal on e-Learning, 2(1), 121-128.

Blignaut, S., \& Trollip, S. R. (2003). Developing a taxonomy of faculty participation in asynchronous learning environments-an exploratory investigation. Computers \& Education, 41(2), 149-172. http://dx.doi.org/10.1016/S0360-1315(03)00033-2

Brown, T. (1999). Challenging globalization as discourse and phenomenon. International Journal of Lifelong Education, 18(1), 3-17. http://dx.doi.org/10.1080/026013799293919

Chen, C. C., \& Yang, S. C. (2006). The efficacy of online cooperative learning systems, the perspective of task-technology fit. Campus Wide Information Systems, 23(3). 
Cheon, J., Lee, S., Crooks, S. M., \& Song, J. (2012). An investigation of mobile learning readiness in higher education based on the theory of planned behavior. Computers \& Education, 59(3), 1054-1064.

Clegg, S., Hudson, A., \& Steel, J. (2003). The emperor's new clothes: globalisation and e-learning in higher education. British Journal of Sociology of Education, 24(1), 39-53. http://dx.doi.org/10.1080/01425690301914

Conrad, D. (2004). University instructor's reflections on their first online teaching experience. JALN, 8(2).

Cornelius, S., \& Macdonald, J (2008). Online informal professional development for distance tutors: experiences from The Open University in Scotland. Open Learning, 23(1), 43-55ISSN 0268-0513 print/ISSN 1469-9958. http://dx.doi.org/10.1080/02680510701815319

Copley, J (2007). Audio and video podcasts of lectures for campus - based students: production and evaluation of student use. Innovations in Education and Teaching International, 44 (4), 387-399. http://dx.doi.org/10.1080/14703290701602805

EduTools (2009). CMS: Product List. Retrieved March 02, 2009.

Eynon, R. (2005). The use of the internet in higher education: Academics' experiences of using ICTs for teaching and learning. In Aslib proceedings, 57(2), 168-180. Emerald Group Publishing Limited. http://dx.doi.org/10.1108/00012530510589137

Evans, C. (2008). The effectiveness of m-learning in the form of podcast revision lectures in higher education. Computers \& Education, 50 (2) 491- 498. http://dx.doi.org/10.1016/j.compedu.2007.09.016

Farmer, J. (2004). Communication dynamics: Discussion boards, weblogs and the development of communities of inquiry in online learning environments. 21st ASCILITE Conference, 274-283.

Gerrard, C. (2002). Promoting Best Practice for E-tutoring through Staff Development, Proceedings of Networked Learning.

Ge, J. D., Hui, L., \& Tingting, Z. (2010). A preliminary study of personal learning environment based on Ubiquitous Computing Model. Ubi-media Computing (U-Media), 2010 3rd IEEE International Conference on (pp. 350-354), IEEE.

Hall, B. (1996) Adult education and the political economy of global economic change. P. Wangoola \& F. Youngman (eds), Towards a transformative political economy of adult education: theoretical and practical challenges (Illinois: LEPS Press).

Hannon, J., \& D'Netto, B. (2007). Cultural diversity online: student engagement with learning Technologies. International Journal of Educational Management, 21(5), 418-432. http://dx.doi.org/10.1108/09513540710760192

Hardaker, G., \& Singh, G. (2011). The Adoption and Diffusion of eLearning in UK Universities: A Comparative Case Study Using Giddens's Theory of Structuration. Campus Wide Information Systems, 28(4), 221-233. http://dx.doi.org/10.1108/10650741111162707

Huddlestone, J., \& Pike, J. (2008). Seven key decision factors for selecting e-learning. Cognition, Technology \& Work, 10(3), 237-247. http://dx.doi.org/10.1007/s10111-007-0102-z

Jackson, S., \& Fearon, C. (2013). Exploring the role and influence of expectations in achieving VLE benefit success. British Journal of Educational Technology. http://dx.doi.org/10.1111/bjet.12029

Leask, B. (2004). Internationalisation outcomes for all students using information and communication technologies (ICTs). Journal of Studies in International Education, 8(4), 336-51. http://dx.doi.org/10.1177/1028315303261778

Macharia, J. K., \& Pelser, T. G. (2012). Key factors that influence the diffusion and infusion of information and communication technologies in Kenyan higher education. Studies in Higher Education, (ahead-of-print), 1-15. http://dx.doi.org/10.1080/03075079.2012.729033

Mee, A. (2012). E-learning policy and the transformation of schooling: a UK case study. European Journal of Open, Distance and E-Learning.

Mihhailova, G (2006). E-learning as internationalization strategy in higher education. Lecturer's and Student's perspective. Baltic Journal of Management, 1(3), 270-284. http://dx.doi.org/10.1108/17465260610690926

Moos, D. C, \& Azevedo, R (2009). Learning with Computer-Based Learning Environments: A Literature Review of $\begin{array}{llllll}\text { Computer Self-Efficacy. Review of Educational Research, } 79 & \text { (2), 576-600. }\end{array}$ http://dx.doi.org/10.3102/0034654308326083

Morley, Graham. (2010). Suggestions to Assist Primary Teachers in Keeping Pace with ICT: Teachers' Experiences in 
England. 2nd International Conference on Education, Economy \& Society, 21-24, Paris, France. (Unpublished).

Nandi, D., Hamilton, M., Chang, S., \& Balbo, S. (2012). Evaluating quality in online asynchronous interactions between students and discussion facilitators. Australasian Journal of Educational Technology, 28(4), 684-702.

Nielsen, D., White, A. S., \& Zhou, L. (2011). The VLE as the converging platform. Electrical Engineering and Informatics (ICEEI), 2011 International Conference on, 1-6, IEEE.

Olaniran, B. A. (2006). Applying synchronous computer-mediated communication into course design: Some considerations and practical guides. Campus-Wide Information Systems, 23(3), $210-220$. http://dx.doi.org/10.1108/10650740610674210

Phipps, R., \& Merisotis, J. (1999). What's the Difference: A Review of Contemporary Research on the Effectiveness of Distance Learning in Higher Education. Journal of Distance Education, 14(1), 102-114.

Raghuram, P. (2013). Theorising the spaces of student migration. Population, Space and Place, 19(2), $138-154$. http://dx.doi.org/10.1002/psp.1747

Reeder, K., Macfadyen, L. P., Chase, M., \& Roche, J. (2004). Negotiating culture in cyberspace: participation patterns and problematic. Language Learning and Technology, 8(2), 88-105.

Salmon, G. (2000). E-moderating: The key to teaching and learning online. Kogan Page, London, 7-10. http://dx.doi.org/10.4324/9780203465424

Shu, Y. L. (2010) Study on IT based teaching evaluation. 2010 international conference on computer design and applications, IEEE Explore.

Sidhu, R. K. (2006). Universities and globalization: To market, to market. Routledge.

Smith, A. D., Morris, R., \& Rupp, W. T. (2003). Managerial implications of computer-based online face-to-face business education: a case study. Online Information Review. 28(2), 100-109. http://dx.doi.org/10.1108/14684520410531682

Spring, J. (2008). Globalization of education: An introduction. Routledge

Sywelem, M., Al-Harbi, Q., Fathema, N., \& Witte, J. (2012). Learning style preferences of student teachers: A cross-cultural perspective. Institute for Learning Styles Journal, 1, 10-24.

Tomei, L. (2006). The impact of online teaching on faculty load: Computing the ideal class size for online courses. Journal of Technology and Teacher Education, 14(3), 531-541.

Wang, W. T., \& Wang, C. C. (2009). An empirical study of instructor adoption of web-based learning systems. Computers \& Education, 53(3), 761-774. http://dx.doi.org/10.1016/j.compedu.2009.02.021

Wangoola, P., \& Youngman, F. (1996). Towards a Transformative Political Economy of Adult Education: Theoretical and Practical Challenges. LEPS Press, Northern Illinois University, DeKalb, IL 60115.

Xin, B. (2010). Promoting a ubiquitous e-learning framework. Computer Science and Information Technology (ICCSIT), 2010 3rd IEEE International Conference, 1, 496-500, IEEE.

Zeffane, R., \& McLoughlin, D. (2006). Cooperation and stress Exploring the differential impact of job satisfaction, communication and culture. Management Research News, 29(10). http://dx.doi.org/10.1108/01409170610712326

Zhang, H., Kitchenham J., \& Jeffery. B. R. (2008), Semi-quantitative Modelling for Managing Software Development Processes. Software Engineering ASWEC 2008 19th Australian Conference, 66-75.

http://dx.doi.org/10.1109/ASWEC.2008.4483194

\section{$(\mathrm{cc}) \mathrm{BY}$}

This work is licensed under a Creative Commons Attribution 3.0 License. 